\title{
耳鼻咽喉科入院患者の咽喉頭異常感
}

\author{
雨皿亮・山際 幹和・坂倉 康夫
}

\section{Abnormal Sensation in the Throat of In-Patients with Otorhinolaryngeal Diseases}

\author{
Ryo Amesara, Mikikazu Yamagiwa and Yasuo Sakakura
}

(Mie University)

Using the Cornell Medical Index-Health Questionnaire (GMI) and the Maudsley Personality Inventory (MPI), we surveyed abnormal sensation in the throat (AST) in 258 in-patients with otorhinolaryngeal diseases at Mie University Hospital.

Patients with pharyngeal, laryngeal, or thyroid disease had a higher incidence of AST than did those with nasal or other diseases. There was a significant relationship between AST and a history of upper respiratory tract diseases. GMI scores revealed that $13.6 \%$ of the patients were classified as manifestly neurotic, and more patients with AST were neurotic (48.5\%) than those without AST (18.2\%).

Key words : abnormal sensation in the throat, GMI, MPI, in-patient

はじめに

咽喉頭部に生じる異常感は極めて頻度の高い 自覚症状であり，一般人の約一割に存在すると

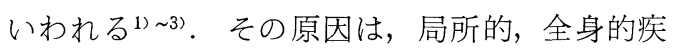
患に由来するものから，全く原因不明のものま で多岐にわたって抢り，さらに心理的要因によ って症状が修飾されている場合も多い屯のと考 えられる，咽喉頭異常感を主訴に来院する患者 以外にあ，程度の差てそあれ異常感を自覚して いる症例はかなり多い印象がある。乙れまでに 一般人を対象にした咽喉頭異常感についての調 查結果が報告されているが(1) 3), 今回は, 当科 に入院し治療を受けた患者を対象に健康調査 $(\mathrm{CMI})^{4)}$ ，とモーズレイ性格検査 $(\mathrm{MPI})^{5)}$ を行 い，異常感の有無とその関連因子について検討 を行った。

\section{対象および方法}

対象は，1986年 2 月から1987年 6 月までの間 に三重大学医学部附属病院耳鼻咽喉科に入院し た17歳以上の患者であり，入院時に CMI およ び MPI を行った. そのうち, 両調査票に完全 な回答をした 258 名について解析を行った。咽 喉頭異常感の有無は, CMI の項目 B-11「のど がつまる感じがよくしますか」に対する回答に よって行い，B-11に「はい」と回答した者を 咽喉頭異常感を有する者（異常感存在群）「い いえ」と回答した患者を咽喉頭異常感を有さ ない者 (非存在群) とした。統計学的計算は Student's t test，あるいは $\chi^{2}$ 検定を用いた.

\section{結果}

I . 疾患別咽喉頭異常感保有率（困 1 ）

図 1 は, 基礎疾患別に咽喉頭異常感の保有率 
を示したものである。乙こでは，異常感に影響 を及ぼす可能性により疾患を分類した。すなわ ち, 口腔 - 咽頭 - 喉頭疾患, 甲状腺疾患, 鼻副 鼻腔疾患と, 耳，耳下腺疾患などのその他疾患 の 4 群とした。腔・咽頭・喉頭に疾患をむつ 患者は異常感を主訴にすることも多く，やはり 全体で39.8\%（43/108） と高い保有率を示した。 甲状腺疾患患者についても全体で32\%（8/25） と, 咽喉頭疾患患者とほぼ同じ割合で異常感が 存在した。鼻副鼻腔疾患は鼻閉による口呼吸や 後鼻漏が異常感を引き起とす可能性があるが， 全体で10\%（6/60）であり，その他疾患の 13.8 \%（9/65） と大差がなかった。

【 。上気道炎との関連（図 2)

図 2 は, CMI の項目 B-16「よくひどいかぜ をひきますか」と，B-16'「よくのどが痛んだ り扁桃がはれたりしますか」のそれぞれに「は い」と回答した者の百分率を示したあのである. いずれの疾患をとってみても異常感存在群の方 に上気道炎の既往のある割合は高い傾向にあっ た，特に，口腔・咽・喉頭疾患患者においては 異常感の存在とかぜをひきやすいとととの間に は有意の関連があり，また，その他疾患患者に おいてはのどが痛む，扁桃がはれるなどの慢性 扁桃炎を示唆する症状と異常感の存在との間に 有意の関連があった。 B-16, B-16' のいずれか または両方に「はい」の回答をした者を異常感 存在群と非存在群とで比較してみると, 口腔・ 咽頭・喉頭疾患患者ではそれぞれ 55.8\%（24/ 43)，30.8\%（20/65），（p<0.01），甲状腺疾 患患者では $50 \%$ （4/8），29.4\%（5/17)，(ns), その他では $46.7 \%(7 / 15), 20 \%(22 / 110)$, $(\mathrm{p}<0.05 ）$ となり，甲状腺疾患患者以外では 統計学的に有意な差を認めた。

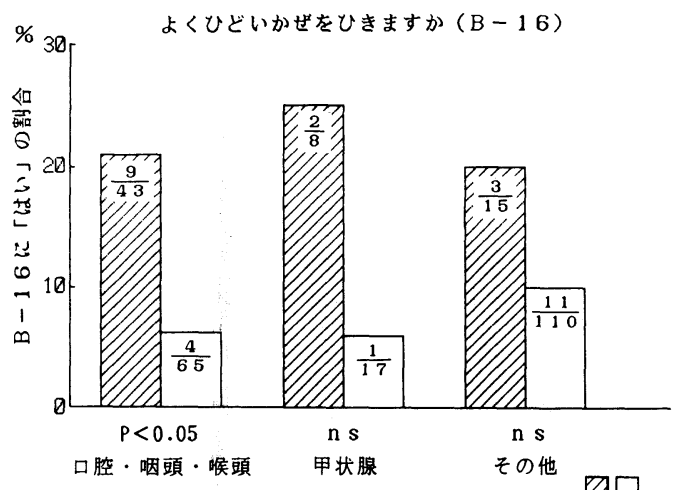

よくのどが痛んだり扁桃腺が
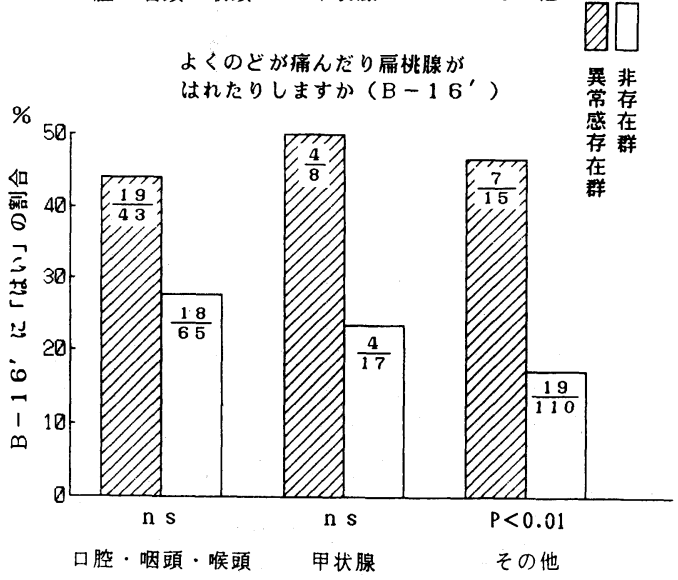

図 2 咽喉頭異常感亡上気道炎

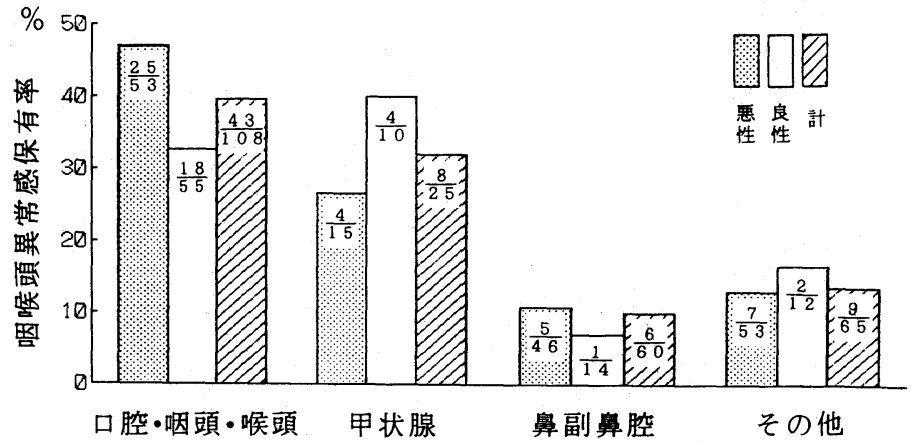

図 1 CMI よりみた疾患別咽喉頭異常感保有率 
III. 神経症的傾向亡の関連

器質的疾患が影響を及ぼす可能性のある咽喉 頭疾患执よ゙甲状腺疾患の群と，その他疾患の 群とにわけて検討した。また悪性疾患患者にお いては，疾患に対する不安から心理状態が修飾 されている可能性があるため，良性疾患とは別 に集計した。

\section{CMI による検討}

図 3 は, CMI において，深町の判定基準 ${ }^{4}$ で 神経症の可能性がある，あるいは神経症と判定 できる領域吕，IVの占める割合を示したもので ある。良性疾患では疾患に関係なく，また悪性 疾患では口腔・咽・喉頭・甲状腺疾患患者にお いて異常感存在群で領域 III, IV の占める割合は 異常感非存在群のそれに比べて有意に高かった。 その他の悪性疾患患者でも同様の傾向はうかが われたが，母数が少なかったことああり，推計
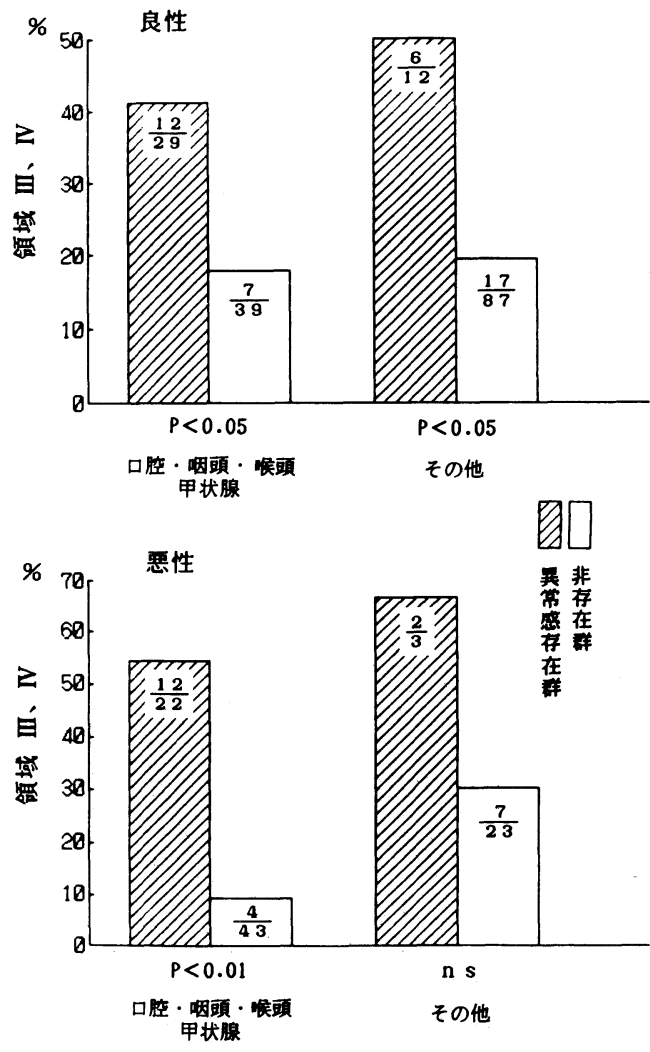

図 3 咽喉頭異常感と CMI による神経症的 傾向の関係
学的には有意ではなかった。しかしながら実際 の領域 $N$ の症例数はそれぞれ少なく(表 1 )，明 らかに神経症といえるような患者は多くないむ のと思われた。

\section{MPI による検討}

表 2 亿 MPI 各尺度の平均得点を示す. 各疾 患別にわけ，咽喉頭異常感の有無別に検討した。 外向性一内向性（E） 尺度はごの比較において あ近似した点数であった。咽喉頭異常感の有無 で神経症的傾向（N）尺度を検討すると，悪性 疾患中の口腔 - 咽 - 喉頭 - 甲状腺疾患患者にお いて異常感存在群の N尺度の得点が有意に高得 点であり，また逆に，悪性疾患中のその他疾患 群において異常感存在群の N尺度は有意に低得 点であった。しかしながら，どの群においても 標準とされる範囲 ${ }^{5)}$ 内にある屯のと考えられ た。また，N尺度については29点以上が神経
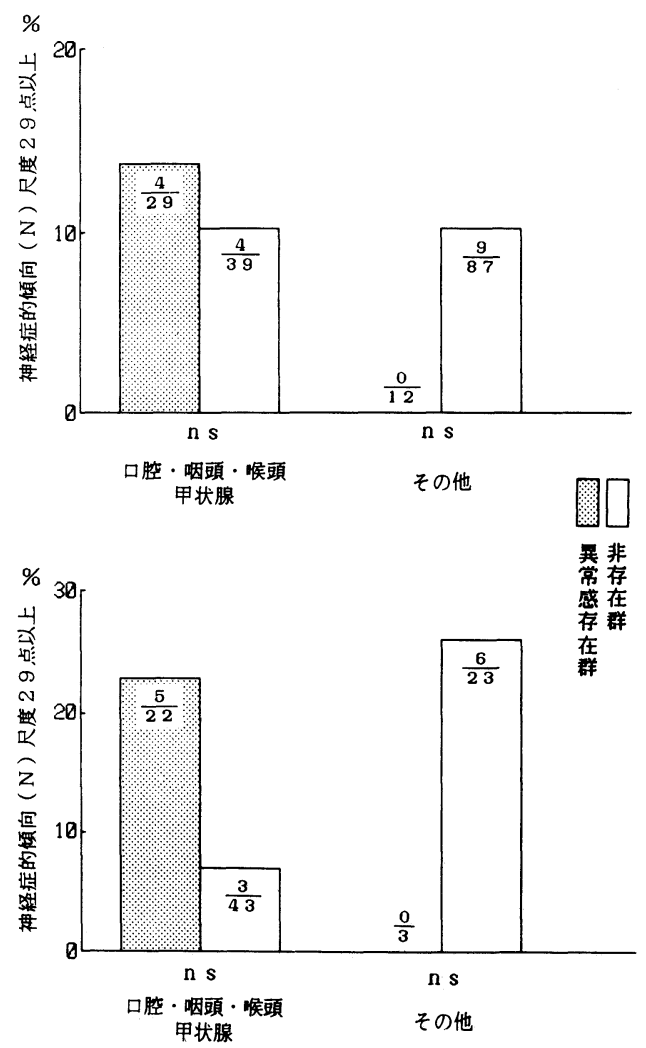

図 4 咽喉頭異常感と MPI による神経症的 傾向の関係 
表 1 深町の分類 ${ }^{4}$ による CMI 領域分布

\begin{tabular}{|c|c|c|c|c|c|c|c|}
\hline & & 域 & I & П & III & IV & 計 \\
\hline \multirow{4}{*}{$\begin{array}{l}\text { 異 } \\
\text { 常 } \\
\text { 感 } \\
\text { 存 } \\
\text { 在 } \\
\text { 群 }\end{array}$} & \multirow{2}{*}{$\begin{array}{l}\text { 良 } \\
\text { 性 } \\
\text { 患 }\end{array}$} & $\begin{array}{l}\text { 口腔, 咽喉頭, } \\
\text { 甲状腺 }\end{array}$ & $5(17.2 \%)$ & $12(41.4 \%)$ & $10(34.5 \%)$ & $2(6.9 \%)$ & 29 \\
\hline & & そ の 他 & $2(16.7 \%)$ & $4(33.3 \%)$ & $5(41.7 \%)$ & $1(8.3 \%)$ & 12 \\
\hline & \multirow{2}{*}{$\begin{array}{l}\text { 覀 } \\
\text { 性 } \\
\text { 疾 } \\
\text { 患 }\end{array}$} & $\begin{array}{l}\text { 口腔, 咽喉頭, } \\
\text { 甲状腺 }\end{array}$ & $4(18.2 \%)$ & $6(27.3 \%)$ & $6(27.3 \%)$ & $6(27.3 \%)$ & 22 \\
\hline & & そ の 他 & $0\left(\begin{array}{ll}0 & \%\end{array}\right)$ & $1(33.3 \%)$ & $2(66.7 \%)$ & $0\left(\begin{array}{ll}0 & \%\end{array}\right)$ & 3 \\
\hline \multirow{4}{*}{$\begin{array}{l}\text { 異 } \\
\text { 常 } \\
\text { 感 } \\
\text { 非 } \\
\text { 存 } \\
\text { 在 } \\
\text { 群 }\end{array}$} & \multirow{2}{*}{$\begin{array}{l}\text { 良 } \\
\text { 性 } \\
\text { 患 }\end{array}$} & $\begin{array}{l}\text { 口腔, 咽喉頭, } \\
\text { 甲状腺 }\end{array}$ & $17(43.6 \%)$ & $15(38.5 \%)$ & $5(12.8 \%)$ & $2(5.1 \%)$ & 39 \\
\hline & & そ の 他 & $40(45.9 \%)$ & $30(34.5 \%)$ & $14(16.1 \%)$ & $3(3.5 \%)$ & 87 \\
\hline & \multirow{2}{*}{$\begin{array}{l}\text { 悪 } \\
\text { 性 } \\
\text { 疾 } \\
\text { 患 }\end{array}$} & $\begin{array}{l}\text { 口腔, 咽喉頭, } \\
\text { 甲胀 }\end{array}$ & $26(60.5 \%)$ & $13(30.2 \%)$ & $3(7.0 \%)$ & $1(2.3 \%)$ & 43 \\
\hline & & そ の 他 & $10(43.5 \%)$ & $6(26.1 \%)$ & $4(17.4 \%)$ & $3(13.0 \%)$ & 23 \\
\hline
\end{tabular}

表 2 MPI 各尺度の平均得点士標準偏差

\begin{tabular}{|c|c|c|c|c|c|c|c|c|}
\hline & & & & 異常感 & $\begin{array}{l}\text { 外向性一内向性 } \\
(\mathrm{E}) \text { 尺度得点 }\end{array}$ & $\begin{array}{l}\text { 神経症的傾向 } \\
\text { (N)尺度得点 }\end{array}$ & 虚偽発見 (L)尺度得点 & $\mathrm{n}$ \\
\hline \multirow{2}{*}{\multicolumn{2}{|c|}{ 総 }} & \multirow{2}{*}{\multicolumn{2}{|c|}{ 計 }} & 有 & $28.2 \pm 11.0$ & $17.1 \pm 10.4$ & $19.9 \pm 7.5$ & 66 \\
\hline & & & & 無 & $28.7 \pm 10.6$ & $14.6 \pm 10.4$ & $19.1 \pm 7.1$ & 192 \\
\hline \multirow{4}{*}{$\begin{array}{l}\text { 良 } \\
\text { 性 } \\
\text { 疾 } \\
\text { 患 }\end{array}$} & \multirow{2}{*}{$\begin{array}{l}\text { 口 } \\
\text { 咽 } \\
\text { 甲 }\end{array}$} & \multirow{2}{*}{$\begin{array}{l}\text { 喉 } \\
\text { 状 }\end{array}$} & \multirow{2}{*}{$\begin{array}{l}\text { 腔 } \\
\text { 䫝 } \\
\end{array}$} & 有 & $31.5 \pm 10.2$ & $14.4 \pm 10.5$ & $20.5 \pm 7.2$ & 29 \\
\hline & & & & 無 & $40.0 \pm 10.4$ & $14.6 \pm 9.0$ & $18.3 \pm 7.2$ & 39 \\
\hline & \multirow{2}{*}{ そ } & \multirow{2}{*}{ の } & \multirow{2}{*}{ 他 } & 有 & $24.8 \pm 10.4$ & $17.2 \pm 9.4$ & $16.7 \pm 8.5$ & 12 \\
\hline & & & & 無 & $28.6 \pm 10.8$ & $13.2 \pm 10.3$ & $18.2 \pm 7.1$ & 87 \\
\hline \multirow{4}{*}{$\begin{array}{c}\text { 覀 } \\
\text { 性 } \\
\text { 疾 } \\
\text { 患 }\end{array}$} & \multirow{2}{*}{$\begin{array}{l}\text { 口 } \\
\text { 咽 } \\
\text { 甲 }\end{array}$} & \multirow{2}{*}{$\begin{array}{l}\text { 喉 } \\
\text { 状 }\end{array}$} & \multirow{2}{*}{$\begin{array}{l}\text { 膣 } \\
\text { 頭 } \\
\text { 腺 }\end{array}$} & 有 & $25.4 \pm 12.1$ & $21.5 \pm 10.27 \quad p<0.01$ & $20.7 \pm 7.8$ & 22 \\
\hline & & & & 無 & $27.5 \pm 10.0$ & $14.4 \pm 9.7\rfloor$ & $21.8 \pm 6.4$ & 43 \\
\hline & & \multirow{2}{*}{\multicolumn{2}{|c|}{ の 他 }} & 有 & $31.3 \pm 4.2$ & $11.0 \pm 1.07 \mathrm{p}<0.01$ & $21.7 \pm 4.5$ & 3 \\
\hline & & & & 無 & $27.7 \pm 11.5$ & $20.0 \pm 12.9] P$ & $18.7 \pm 7.3$ & 23 \\
\hline \multicolumn{5}{|c|}{ 得点カテゴリー5) } & $\begin{aligned} & 0 \sim 9: \text { 非常に内向的 } \\
& 10 \sim 20 \text { :やや内向的 } \\
& 21 \sim 31 \text { : 普通 } \\
& 32 \sim 41: \text { やや外向的 } \\
& 42 \sim 48: \text { 非常に外向的 }\end{aligned}$ & $\begin{aligned} 0 \sim 8 & : \text { 神経症的傾向 } \\
& \text { 殆どなし } \\
9 \sim 18: & \text { 神経症的傾向 } \\
& \text { は低 } \\
19 \sim 28: & \text { 普通 } \\
29 \sim 38: & \text { 神経症的傾向 } \\
& \text { がある } \\
39 \sim 48: & \text { 神経症的傾向 } \\
& \text { が非常に強い }\end{aligned}$ & $\begin{aligned} & 0 \sim 6: \text { 低得点カテゴ } \\
& \text { リ〜 } \\
& 70: \text { 中得点カテゴ } \\
& \text { リー } \\
& 21 \sim 40: \text { 高得点カテゴ } \\
& \text { リー }\end{aligned}$ & \\
\hline
\end{tabular}


症の可能性があるとされている5) ので，29点以 上の症例数を図 4 亿示す。症例数が少ないため に充分な解析ができないが，今回の検討ではは っきりとした傾向は認められなかった。

\section{考察}

咽喉頭異常感はその実態を把握しにくい症状 であり, 実際, 局所的な器質的疾患, 内分泌系 や自律神経系の変調，さらには精神的な要因な どが複雑に影響しているものと考えられる677.

山際ら 2338) は局所的要因として咽頭の慢性炎症 を重視しており，注意深い観察により異常感を 有する例で炎症所見を見る比率が高いとしてい る。また山田と矢野原 91 は，咽喉頭異常感症患 者において超音波検査上, 甲状腺の小結節が高 率に発見されたとしている。 今回の調査結果に 拈いても同様に咽喉頭疾患之甲状腺疾患の患者 の $3 \sim 4$ 割に異常感が存在していた。 入院治療 を要する患者であるととを考慮する必要はある が，乙れは，10数\%という一般人における異常 感保有率 ${ }^{11}$ ３) に比べると明らかに高率であると いえよう。ささらに，上気道感染を抢てしやすい ことや，慢性扁桃炎の存在を示唆するCMI の 質問 B-16, B-16' の「はい」の回答が異常感 存在群に高い傾向にあることは異常感の発現に 局所の器質的な要因が何らかの形で関与するこ とを示すあのである.

一方，日常診療において異常感を訴える患者 のなかでは，平野6) のいう「器質的疾患が認め られるが，それだけからとは考えられない異常 感を訴えるもの」，「器質的疾患が認められない のに異常感を訴えるもの」というあのがかなり 多い印象をうける。乙れらを咽喉頭異常感症之 呼称するならば，乙の咽喉頭異常感症と神経症 的傾向との間には密接な関連のあるととが報告 されている ${ }^{10111}$ 。また，咽喉頭異常感がうつ病 の部分症状であったととああり ${ }^{12)}$ ，精神医学的 なアプローチあきわめて重要であると思われる. 今回の検討では CMI の領域分布（深町の基 準 ${ }^{4)}$ による）と，MPI の各尺度の平均得点によ り神経症的傾向を評価した. CMI の領域II,
INを示す割合は異常感存在群で明らかに大きく， 局所の疾患が異常感の原因であるにせよ，心理 的状態が症状の修飾因子であるととを示唆する. このIII， IVの占める割合は，山際ら ${ }^{13)}$ の成績に よる領域 I 33\%， I 33\%，而25\%，IV $9 \%$, 金久と深町 ${ }^{4)}$ による領域 I 38\%， II 37\%， II 22 \%，IV $3 \%$ に比べると高率であるが，入院患者 という特殊事情によるものかも知れない。しか しながら領域 $N$ に限ると悪性の口腔・咽・喉頭 ・甲状腺疾患患者をのぞいて，乙れらの報告と 大差はなく，明らかに神経症と診断できるほど のものではなかった。

MPI 調查 ${ }^{5}$ は，神経症的傾向 と外向性一内 向性の測定を目的としたあのである．神経症的 傾向は $\mathrm{N}$ 尺度の得点で表わされ，29点以上で神 経症的傾向があるとされる，また，外向性一内 向性は $\mathrm{E} 尺$ 度の得点で表され，21〜31点が「普 通」と分類され，20点以下が内向的，32点以上 が外向的と分類される。 さらに MPI では回答 者が各質問に対して正直に答えたかどうかを調 べる尺度としてL尺度が設けられており,7〜20 点が中得点カテゴリー，21点以上が高得点カテ ゴリーとされている，得点が高いほど虚偽の回 答のために結果が歪められている可能性がある. 今回の検討では，E尺度については特記すべき 傾向は認められず，N尺度においても悪性疾患 患者に扔いて異常感の有無によって得点に差が あるあのの，いずれも神経症的傾向があるとは いえない範囲であった。これらの傾向は山際 ら ${ }^{13)}$ の報告と類似するすのであった。しかしな がら L 尺度の平均は中得点カテゴリーの上限も しくは高得点カテゴリーに相当しており，入院 患者という，決して心理的に正常な状態である とは限らない症例を扱うことの困難さをあらた めて認識させられた。

咽喉頭異常感は心理的要素の強い症状である とはいえ，その基礎にある局所的な疾患をみの がすととのないよう検索をすすめることが必要 である．神経症にすぎないと安易にすましてし まうことは避けねばなるまい。 


$$
\text { まとめ }
$$

三重大学医学部附属病院耳鼻咽喉科入院患者 258名を対象として咽喉頭異常感とその身体的 および精神的自覚症状あるいは神経症的傾向な よ゙を質問紙法により調査し，以下の結果を得た。

1 ）咽喉頭異常感の保有率は口腔・咽・喉頭 疾患上甲状腺疾患患者に高率であった。

2 ）上気道炎の既往と異常感の存在との間に は関連がある傾向がみられ，特に咽喉頭疾患患 者における急性上気道炎，その他疾患患者にお ける慢性扁桃炎の既往は咽喉頭異常感との間に 有意の関連がみられた。

3）深町の分類によるCMI の領域分布をみ ると異常感を有する患者において神経症的傾向 を示すとされる領域III，IVの占める割合が有意 に高率であった。

4) MPI の神経症的傾向（N） 尺度得点は, 咽喉頭異常感の有無と明らかな関連性を示さず， また明らかに神経症と診断できる症例も少なか った.

\section{参考文献}

1 ）佐々木治夫：一農村における咽喉頭異常感につい て. 耳喉 39：625～629，1967.

2 ）山際幹和, 福生治城, 西岡博之, 他: 60歳以上例 を対象とした咽喉頭異物感に関する調査成績．日 耳鼻 $87: 1519 \sim 1526 ， 1984$.

3 ）山際幹和, 原田輝彦, 福喜多啓三, 他 : 学童, 生 徒を対象之した咽喉頭異常感に関する調査成績。
日耳鼻 90 : 50〜 58, 1987.

4 ）金久卓也, 深町 建: コーネル・メディカル・イ ンデックス. 三京房, 京都, 1980 .

5 ) MPI 研究会：新・性格検査法 —モーズレイ性格 検査一。誠信書房, 東京, 1981 .

6 ）平野 実：咽喉頭異常感症．耳鼻臨床 70：997 1015, 1977.

7）三宅 弘：咽喉頭異常感. 耳喉 46：703 709, 1974.

8 ) 山際幹和, 久保将彦, 原田輝彦, 他：咽喉頭巽常 感症患者の咽頭所見.耳鼻臨床 $81 ： 409 \sim 415$, 1988.

9）山田弘之, 矢野原邦夫：咽喉頭異常感患者におけ る甲状腺超音波診断の意義. 耳喉 59 ：587〜 591， 1987.

10）里見真美子：咽喉頭異常感症の臨床的観察.耳鼻 臨床 73 増 $1 ： 463 \sim 467,1980$.

11）日野原正：咽喉頭異常感について一心身症の立場 から一。聑喉 $40: 213 \sim 217,1968$.

12）三好 彰，河本和友：咽喉頭異常感を主訴として 当科受診した Depression の 1 症例. 耳鼻 27： 604 607, 1987.

13）山際幹和, 北畠正義, 福生治城, 他 : 咽喉頭異常 感症例の統計的観察. 耳鼻臨床 $79: 1823 \sim 1840$, 1986.

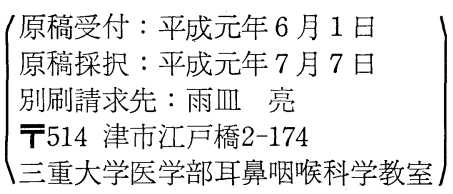

